\title{
BUSINESS AND WELFARE STATE DEVELOPMENT \\ Why Did Employers Accept Social Reforms?
}

\author{
By THOMAS PASTER*
}

\section{INTRODUCTION}

TOW do business groups perceive the adoption of public programs 1 that offer social protection to workers? The conventional view of business as being opposed to social protection, implied in accounts emphasizing labor power or the autonomy of government bureaucracies, ${ }^{1}$ came under challenge in recent years from what this article terms the business interests thesis. The thesis suggests that the adoption or expansion of social programs often stems from the power of business interests, rather than from their weakening. ${ }^{2}$ This view implies that differences in the generosity and characteristics of social programs reflect, to a significant extent, differences in business preferences. Historical institutionalist and power resource scholars have taken issue with this approach on both empirical and theoretical grounds, as they have questioned the importance of employers' impact on reforms as well as the specification of business preferences and strategies in business-centered accounts. ${ }^{3}$

In this article, I take issue with the business interests thesis and offer an alternative explanation of business support for social policy expansion.

*For helpful comments and criticism, I wish to thank the three anonymous reviewers and Alexandre Afonso, James Cronin, Elke Heins, Alexander Hicks, Martin Höpner, Achim Kemmerling, Daniel Kinderman, Mathieu Leimgruber, Aldo Madariaga, Philip Manow, Isabela Mares, Paul Marx, Julia Moses, Herbert Obinger, Georg Picot, Sven Steinmo, and Tobias ten Brink.

${ }^{1}$ Esping-Andersen 1985; Huber and Stephens 2001; Korpi 1983; Shalev 1983; Skocpol 1992.

${ }^{2}$ Iversen and Soskice 2009, 481; Jenkins and Brents 1991; Jenkins and Brents 1989; Mares 1997; Mares 2003a; Martin 2004; Martin and Swank 2011; Swenson 2002; Swenson 2004.

${ }^{3}$ See Amenta and Parikh 1991; Hacker and Pierson 2002; Huber and Stephens 2001; Korpi 2006; Nijhuis 2009.

World Politics 65, no. 3 (July 2013), 416-51

Copyright (C) 2013 Trustees of Princeton University

doi: 10.1017/S0043887113000117 
Building on a cross-temporal comparison of different periods in the development of the welfare state in Germany, the article investigates why employers took different policy stances in different periods. Why did employers support some reforms but not others? The article challenges the assumption frequently made in employer-centered accounts, that employers backed social reforms because they expected economic benefits in terms of greater labor productivity or efficiency. Similar to studies by Hacker and Pierson and by Korpi, ${ }^{4} \mathrm{I}$ argue that changes in political context induced major business groups to change their social policy attitudes.

In diverging from their accounts, however, I argue that business support for social reforms reflects a response not only to the strength of labor or other pro-welfare actors but also and equally importantly to the character of the political challenges that business confronts. The article distinguishes between two types of challenges: revolutionary and reformist. Revolutionary challenges are the result of anticapitalist movements that are strong enough to cause political instability; reformist challenges are the result of initiatives for social reform that threaten to raise labor costs or restrict entrepreneurial freedom. Employers' attitudes toward social policy expansion will vary depending on the type and the strength of the challenge they confront. To describe this variation in employers' goals and motives, the article uses two concepts: social pacification and policy containment (see Table 1).

Political and economic elites have two options for dealing with revolutionary challenges: repression and pacification. Repression means imposing constraints on the scope for political activities of opposition groups; pacification means granting rights or benefits to discontented groups in order to erode support for revolutionary movements. Only authoritarian regimes have the capacity for effective repression; liberal-democratic regimes do not. Thus, in a context where repression is either unavailable or appears insufficient, pacification offers an alternative way to maintain political stability.

I argue that those rare cases where business interests actively promoted the adoption or expansion of public social programs reflected such a strategy of pacification. Fear of expropriation or loss of entrepreneurial freedom is the main motive behind business advocacy of welfare expansion. A necessary condition for this strategy of pacification is the existence of a credible anticapitalist force of sufficient strength. If this argument holds, we should not expect to find evidence of business

\footnotetext{
${ }^{4}$ Hacker and Pierson 2002; Korpi 2006.
} 
TABLE 1

Business Strategies in Social Policy-Making

\begin{tabular}{llll}
\hline \hline Strategy & Political Context & Role of Business & $\begin{array}{l}\text { Impact of Business on } \\
\text { Welfare State Expansion }\end{array}$ \\
\hline Pacification & revolutionary & proactive & propels expansion \\
Containment & reformist & defensive & limits expansion \\
\hline
\end{tabular}

groups actively promoting the adoption or expansion of public social programs in the absence of such a force.

The second business strategy in welfare state politics is policy containment, that is, limiting the scope and generosity of proposed social reforms. This is business's default strategy when facing a reformist challenge. Such a challenge exists if, in the absence of a revolutionary challenge, other actors promote the adoption or expansion of social programs and these plans appear likely to succeed. In such a situation, employers will try to limit the reform effort by promoting policy choices that are less costly to them but that still appear capable of winning a majority. If neither a revolutionary nor a reformist situation exists, employers will remain passive on issues of welfare state expansion and will not promote expansionary reforms. In other words, to use the terminology suggested by Walter Korpi, ${ }^{5}$ employers are protagonists of social protection in revolutionary situations, consenters in reformist situations, and opponents if neither situation exists.

The strategies of pacification and containment differ in their impact on reforms. In the case of pacification, employers genuinely propel the adoption of labor-friendly policies; in the case of containment, they obstruct it. In the case of pacification, employers act proactively; in the case of containment, they merely respond to proposals put forth by others. In the case of pacification, employers' political interventions boost welfare state generosity; in the case of containment, they constrain it.

This article tests the validity of this model based on an in-depth analysis of Germany and on two shadow cases, Sweden and the United States. The choice of Germany meets the criterion of a difficult case, a case that one might not expect to fit the article's argument. In comparative political economy, Germany is often identified as a paradigmatic case of a type of market economy where social protection fits the needs

${ }^{5}$ Korpi 2006, 171. 
of employers well. Studies inspired by the varieties of capitalism (VoC) framework of Peter Hall and David Soskice ${ }^{6}$ in particular suggest that Germany's social policies and industrial relations institutions contribute to institutional complementarities that generate competitive advantages to firms. ${ }^{7}$ The alternative view that expectations of higher levels of skills or labor productivity motivated business to promote social reforms ${ }^{8}$ thus appears to have plausibility in Germany. The shadow case studies are intended to test the argument's degree of generalizability.

The article is structured as follows: the first part discusses why and how political challenges shape the way employers perceive their social policy interests and presents the research design of the study. The following two sections analyze episodes of welfare reform taken from different periods in the development of the German welfare state that were characterized by different types of political challenges to business interests. The second section analyzes two reform episodes that reflected a strategy of pacification: the adoption of social insurance in the 1880s and of the Stinnes-Legien Agreement (1918). The third section analyzes three reform episodes that exemplify an employer strategy of containment: the adoption of unemployment insurance (1927), the expansion of pension benefits (1957), and the adoption of long-term care insurance (1994). ${ }^{9}$ The fourth section presents the findings from the two shadow cases, Sweden and the United States.

\section{Business Interests and the Welfare State}

Employer-centered accounts of welfare state development often focus on sectoral differences to identify the sources of employers' social policy preferences. They often highlight differences in interests such as those between tradable and sheltered sectors, ${ }^{10}$ between high-skill and low-skill sectors, or between large and small firms. ${ }^{11}$ According to these accounts, social reforms are often the product of cross-class alliances that result from these sectoral cleavages of interest. ${ }^{12}$

\footnotetext{
${ }^{6}$ Hall and Soskice 2001.

${ }^{7}$ See, for instance, Hassel 2007; Thelen 2001; and Wood 2001.

${ }^{8}$ This argument is highlighted, for instance, in some of the work by Isabela Mares. See Mares 2003a, 250-51.

${ }_{9}$ The analysis of the German case builds on my research published in Paster 2009; Paster 2011; and Paster 2012. The analysis excludes the Nazi period, because the Nazi regime did not allow any independent form of political interest representation. For this reason, we have no credible sources of data about the opinions of German employers on the social policies of the Nazis.

${ }^{10}$ Swenson 1991, 531.

${ }^{11}$ See, for example, Mares 2003b, 237-43; Quadagno 1984, 646.

${ }^{12}$ See, for example, Jenkins and Brents 1989; Levine 1988 on the US New Deal reforms; and Hellwig 2005, 114, on the introduction of unemployment insurance in the UK.
} 
The article takes a different approach: it analyzes variation across time, rather than across sectors or countries. I argue that if we look at changes in employers' social policy attitudes across time, rather than across sectors, the role of political constraints in shaping their goals and strategies becomes evident. This holds true for both long-term and short-term changes. The shift from pacification to containment becomes visible only over the long run. In the Wilhelmine Empire (1871-1918) and the early years of the Weimar Republic, pacification and fear of socialism were the main concerns motivating business support for social reforms. As shown in the empirical analysis, with the reformist transformation of the labor movement, containing reform efforts became the dominant goal of employers.

The analysis of short-term changes in policy positions allows us to control for factors that are likely to change only over a long period. Changes in economic structure, for instance, are unlikely to explain short-term shifts in policy positions, as these changes are likely to occur slowly. Similarly, if we know that no change in political institutions or in the organizational structures of employers' associations took place during a specified period, we can exclude those factors as explanations for a shift in policy positions at that time. A focus on temporality allows us to trace the causes of such short-term changes.

As this article shows, employers often made sudden shifts in their policy positions that cannot be explained by secular shifts in economic structure. Changes in economic interests cannot explain, for instance, why employers in 1918 endorsed the adoption of the eight-hour workday and then retreated from this position just a few years later, even though no significant change had occurred in the interim in either the organizational setup of employers' associations or the sectoral structure of the economy. Nor can changes in economic structures explain why employers endorsed a bill for unemployment insurance in 1927, even though they had fought against it just a few years earlier.

These changes over time in employers' expressed preferences are best explained, I contend, by changes in the political context, rather than by changes in underlying economic interests. Following studies by Hacker and Pierson ${ }^{13}$ and by Korpi ${ }^{14}$ I argue that business support for social reforms reflects an adaptation to political constraints that are the product of two factors: the power resources of other actors and the type of political demands these other actors make. An actor who is politically powerful will not pose a constraint on employers' interests if

${ }^{13}$ Hacker and Pierson 2002.

${ }^{14}$ Korpi 2006. 
its preferences are in line with those of employers. At the same time, an actor who takes an antibusiness stance will not pose a constraint if the actor is very weak. As a result, the extent to which business will accommodate to constraints depends not only on the strength of its opponents but also on the character of their demands. Radical opponents are likely to provoke pacification; reformist ones, containment.

The microfoundations of business interests on which this article builds differ from those of the business interests thesis, which emphasizes that public social policies serve the needs of certain types of firms, in particular, with respect to skills supply, labor productivity, and personnel management. Proponents of the business interests thesis suggest that business support for social policy is the product of objective entrepreneurial needs that are unrelated to political context. In contrast, the argument presented here suggests that changes in political challenges affected employers' social policy attitudes much more than did expectations of economic benefits. This argument raises the question of why the objective needs of industrial production would be insufficient to induce business to support public social policy. The answer is, as Nijhuis has pointed out, that firms can rely on occupational social policies to achieve the same benefits. ${ }^{15}$ Occupational social policies give firms greater control over benefit conditions, allowing them, for instance, to sanction "work shirkers" and to reward loyalty and productivity. In short, from the perspective of skill investments and labor productivity, we can expect firms to prefer occupational to public social policy.

If we take into account employers' capacity to use occupational social policy, the conventional assumption of a genuine business preference against public social policy regains plausibility. The conventional assumption relies on two types of effects. First, public social programs raise labor costs, assuming they are financed by payroll taxes and that they do not replace occupational programs. Second, public social programs are likely to have negative effects on labor supply because they raise workers' reservation wages. ${ }^{16}$ Assuming a limited labor supply, employers thus have an interest in upholding work incentives by limiting individuals' alternatives to gainful employment.

\section{Three Empirical Tests: What Factors Shape the Social Policy Positions of Business?}

The existence of alternative hypotheses about employers' interest perceptions raises the question of how to identify the correct one. How

${ }^{15}$ See Nijhuis 2009, 299.

${ }^{16}$ See Esping-Andersen 1990, 22. 
do we know whether business support for a reform reflects objective entrepreneurial needs for labor productivity and skill investments or whether it reflects a strategic response to a political challenge? Clearly, we cannot observe preferences but can only infer them based on our observation of their empirical implications, as Korpi has noted. ${ }^{17}$

This article relies on three types of empirical implications to test the alternative explanations. First, it analyzes statements issued by employers' associations during policy-making processes to identify the arguments they used to justify their positions. Specifically, minutes of meetings and internal memos are used to analyze their motives.

Second, the article investigates the role of business groups in the initiation of reform projects. Those actors having a genuine interest in a policy should proactively demand its adoption, rather than merely signaling consent once other actors propose it. The article thus considers the stage in policy-making in which employers got involved. Did they propose the policy that was adopted or, alternatively, did they articulate support only once other actors moved the policy onto the agenda? Some might argue that employers' associations may decide for strategic reasons not to propose policies but to rely instead on affiliated policy experts or political parties that act as proxies for business interests. ${ }^{18}$ Thus, a lack of proactive involvement may not indicate a lack of genuine support. For this argument to hold, however, employers' associations would still need to consent to, or at least not oppose, those proposals advocated by their assumed proxies. If we find that the assumed proxies did not take a proactive role either, or that employers' associations criticized their proposals, we can infer that business interests did not propel the reform.

Third, and most important, the article relies on an analysis of diachronic variation, as outlined earlier. If the argument presented here is correct, we should find that employers' attitudes change over time in response to changes in the political challenges they face. The collapse of a revolutionary movement, for instance, should make employers withdraw concessions made under the impression of this threat, if the goal of political stabilization genuinely motivated these concessions. Similarly, the long-run ideological transformation of the labor movement from a revolutionary to a reformist orientation should have intensified employers' concerns about welfare state containment.

\footnotetext{
${ }^{17}$ See Korpi 2006, 181.

${ }^{18}$ Peter Swenson, for instance, argues that during the US New Deal reforms, individual progressive businessmen had incentives "to lie low and wait for outside forces to push for change" (Swenson 2002, 13), partly out of fear of sanctions from conservative business groups.
} 
At the same time, sectoral differences should play a secondary role if political challenges shape employers' social policy positions. Sectoral differences in policy positions are likely to reflect differences in economic conditions, rather than in political context, since the latter is the same for all sectors. If we find employers to be split, with different sectors taking different stances and forming cross-class alliances, this would indicate genuine differences in economic interests. By contrast, if we find employers speaking with a single voice, this would indicate that sectoral differences are not strong enough to prevent the forging of a common position. This does not mean that internal differences do not exist; it means, rather, that the political challenges are strong enough to induce employers to sideline their disagreements.

The case study on Germany assesses the relative weight of sectoral conflicts through an analysis of the level of organization at which employers articulate their social policy positions: German firms organize in employers' associations at the sectoral, regional, and national levels. Sectoral and regional associations together form a national peak federation, the Federation of German Employers' Associations (Bundesvereinigung deutscher Arbeitgeberverbände, BDA). ${ }^{19}$ If the peak federation acts as the main representative of business in policy-making, with sectoral groups taking a back seat, we can infer that employers managed to overcome internal disagreements. By contrast, if sectoral groups are the main actors in policy-making and take conflicting stances, we can infer that sectoral conflicts were too strong to allow the formation of a united stance.

\section{Employers' Strategy of Pacification}

The goal of political stabilization shaped employers' attitudes toward two major reforms in the development of the German political economy: Bismarck's decision in the 1880s to adopt social insurance programs and the Stinnes-Legien Agreement, signed between union leaders and a group of industrialists in November 1918. In both cases, a perceived challenge to capitalism motivated major segments of industry to actively promote concessions to labor-in the first case on social protection, in the second on participation and bargaining rights.

Pacification I: Employers and Bismarck's Social Reforms During the 1880 s the national government introduced public programs for health insurance (1883), accident insurance (1884), and old-age and

${ }^{19}$ Grote, Lang, and Traxler 2007, 156-57. 
disability pensions (1889). Chancellor Bismarck promoted these reforms, which served to appease industrial workers without conceding full democratization. ${ }^{20}$ Bismarck's remark that a social revolution would "eat up sums of a different order" 21 than his social programs illustrates the logic of his reasoning.

The German Empire, founded in 1871 as a merger of regional states, was an authoritarian monarchy, with universal suffrage but with government accountable to the emperor, not to parliament. Political support for the new regime came from heavy industry, the landed aristocracy (Junkers), and the military. Opposition to the new political regime came from the Catholic Church, which had strong regional allegiances, and the emerging organizations of the labor movement, in particular the Social Democratic Party (Socialdemokratische Arbeiterpartei, SAP) founded in $1875 .{ }^{22}$ In theory, the SAP was a revolutionary party committed to the overthrow of capitalism; in practice, however, it restricted itself to parliamentary activities. ${ }^{23}$

Government and industry formed an alliance to keep the SAP out of power. Industrialists ultimately wanted to prevent collectivization. To this end, they opposed further democratization, as democratization might have brought the SAP to power. To keep the SAP weak, government and industry pursued a strategy of carrots and sticks. In 1878 the parliament passed a law that banned the Social Democrats from most political activities outside of parliament. At about the same time, the government bureaucracy began work on plans for the introduction of social insurance. ${ }^{24}$ Support for social insurance came primarily from heavy industry, which was the politically dominant segment within industry at that time. ${ }^{25}$ In 1879 the general assembly of the Central Association of German Industry (Centralverband deutscher Industrie, CDI), which was dominated by heavy industry ${ }^{26}$ endorsed Bismarck's social insurance plans. ${ }^{27}$ Heavy industry was conservative, loyal to

\footnotetext{
${ }^{20}$ Wehler 1997, 132-36.

${ }^{21}$ Quoted in Wehler 1997, 132-36.

${ }^{22}$ See Böhme 1978. The founding of the SDAP resulted from a merger of two factions.

${ }^{23}$ Lidtke 1966, 53-56, 287.

${ }^{24}$ The intention to repress social democracy with the help of social reforms was declared by Emperor Wilhelm I in his Imperial Message of November 17, 1881. See Ayass, Tennstedt, and Winter 2003, 61-64.

${ }^{25}$ See Breger 1982, 15-16; Büren 1934, 54.

${ }^{26}$ See Ullmann, 1979, 594-95. The composition of the CDI's general assembly documents the dominance of heavy industry: the general assembly consisted of three hundred members, whereby sixty-seven votes were held by the Association of German Iron and Steel Industry (VDESI), thirty-eight by the Rhenish-Westphalian coal mines, and ten by Krupp. By comparison, the Association of German Metal Industrialists held only four votes (Ullmann 1977, 176).

${ }^{27}$ See Büren 1934, 52-53; and Bueck 1905, vol. 2.
} 
Bismarck, and antiunion, and it pursued an authoritarian approach to labor relations. ${ }^{28}$

Several quotes help to document industry's pacificatory motives: Fritz Kalle, a representative of the chemical industry and National Liberal deputy, ${ }^{29}$ pointed out that social peace is only possible "if the obvious injustices in our social conditions-which provide the Social Democrats with the opportunity to persuade even the quiet elements of the working population of the abjection of the current situation and thereby gain their support for [the party's] revolutionary plans - are further eliminated." ${ }^{30}$ Similarly, Wilhelm Oechelhäuser, an energy entrepreneur and National Liberal deputy, ${ }^{31}$ argued that "the best way to weaken the ... Social Democrats is to fulfill that part of their demands that every philanthropist has to accept as legitimate." ${ }^{2}$ Wilhelm Beumer, a representative of heavy industry ${ }^{33}$ and future deputy executive director of the CDI, argued that if the reform "help[s] the workers we have to support it; [if] it help[s] the Social Democrats we have to oppose it." ${ }^{34}$ In retrospect (1905), however, CDI executive director Henry Axel Bueck deplored that the reforms had failed to achieve "the goal to conciliate the masses." 35

In addition to the goal of political stabilization, industry supported the reforms to overcome existing liability rules and to prevent a tightening of rules for worker protection. This holds true, in particular, for the adoption of accident insurance. Existing liability rules required injured workers to sue their employers to gain compensation, which aggravated class conflicts and fueled union agitation against allegedly reckless employers. For this reason, injury-prone heavy industry promoted accident insurance. ${ }^{36}$

On November 2, 1880, Louis Baare, director of the steel producer Bochumer Verein and a confidant of Bismarck, convened a group of industrialists to draft a proposal for accident insurance, to be pre-

${ }^{28}$ See Kaelble 1967, 56-57; and Böhme 1966, 387-92.

${ }^{29}$ In 1877, Fritz Kalle cofounded the Association of the German Chemical Industry (then called the Verein zur Wahrung der Interessen der chemischen Industrie). He was also deputy of the National Liberal Party.

${ }^{30}$ Quoted in Breger 1982, 87.

${ }^{31}$ Wilhelm Oechelhäuser was executive director of an energy utility firm and founder of a local employer association in Dessau (Verein anhaltischer Arbeitgeberverbände) that promoted social benefits and worker participation as tools to weaken the Social Democrats. See Leckebusch 1966, 25-26.

${ }^{32}$ Oechelhäuser 1889, 109.

${ }^{33}$ From 1887 on, Beumer was executive director of the Ruhr area branch of the Association of German Iron and Steel Industrialists (Kaelble 1967, 56).

${ }^{34}$ Kaelble 1967.

${ }^{35}$ Bueck 1905, 792.

${ }^{36}$ Breger 1994, 43; Büren 1934, 52-59. 
sented to the government. ${ }^{37}$ The CDI welcomed Baare's initiative. ${ }^{38}$ The minutes of the conference provide valuable insights into the participants' deliberations. Baare warned his fellow industrialists not to set benefit levels too low, as the government might otherwise tighten liability rules. ${ }^{39}$ Another participant said that "resistance ... would be to no avail, because the current general mood is ... against industry, one would simply ignore industry," ${ }^{40}$ meaning that government might go ahead with tighter liability and protection rules. These quotes show that industrialists promoted accident insurance also as an alternative to tighter liability and protection rules.

Improving labor productivity by reducing the incidence of work accidents was not a significant motive. Industry's opposition to tighter laws for worker protection makes this evident. Improved worker protection might have benefited labor productivity. Nevertheless, industry opposed such rules, which were proposed by the government bureaucracy and by the SAP, because it perceived such rules as excessive interference in the internal matters of firms. ${ }^{41}$

To what extent did the CDI and the Baare group of industrialists represent the views of industry at large? How important were sectoral conflicts? The most informative and representative source on this issue is a survey of regional chambers of commerce conducted by the Prussian Statistical Office in 1881. Chambers were regional organizations with compulsory membership and thus tended to represent the interests of smaller firms. According to this survey, 53 percent of all chambers preferred the accident insurance bill of 1881 to the Employers' Liability Law of 1871. By contrast, 39 percent preferred the Employers' Liability Law to the insurance bill. ${ }^{42}$ This shows that views within the business community were indeed diverse. According to a study by Ullmann, a majority of firms opposed Bismarck's reforms, with opposition coming mainly from very small firms, manufacturing firms, and firms in tradable sectors. ${ }^{43}$ These groups reflected diverse interests and were not as well organized as heavy industry, and for this reason they remained politically ineffectual. ${ }^{44}$ In short, the CDI and heavy industry had the capacity to dominate the articulation of business interests, ${ }^{45}$

\footnotetext{
${ }^{37}$ Baare 1880; Breger 1994, 26.

${ }^{38}$ Bueck 1905, 84.

${ }^{39}$ The article relies on a reprint of the minutes in Breger 1994, 53.

${ }^{40}$ Breger 1982, 55.

${ }^{41}$ Berlepsch 1994; Seeber and Fesser 1994, 97-99.

${ }^{42}$ Francke 1881.

${ }^{43}$ Ullmann 1979, 587-88, 592. See also Büren 1934, 54; and Vogel 1951, 43-44.

${ }^{44}$ Ullmann 1977, 171.

${ }^{45}$ Hennock 2007, 190.
} 
which resulted in the sidelining of intrabusiness conflicts in the policymaking process.

It is important to note that pacification was a response not merely to a rise in the strength of social democracy but also to the perceived militancy of this movement. The SAP was still weak and no social revolution was imminent, but the authoritarian worldview of government and industry made them particularly sensitive to any form of radical opposition. ${ }^{46} \mathrm{~A}$ further rise of the SAP might have endangered the conservative government, which industry saw as the patron of its interests.

In terms of its parliamentary strength, the SAP was still weak at the time in comparison with later periods. The SAP gained only 3 percent of parliamentary seats in 1881 and 6 percent in 1884, compared with 27.7 percent in $1912 .{ }^{47}$ Similarly, the strength of the unions began to soar only from the late 1880 s onward-that is, after the adoption of Bismarck's reforms. In 1878, when planning of the reforms began, the social democratic unions counted 56,275 members. The number increased to 111,245 in $1888 ; 294,551$ in 1891 ; and 680,427 in $1895 .{ }^{48}$ Industry's support for pacification resulted from fears of labor militancy, rather than from the objective strength of labor.

\section{Pacification II: The Stinnes-Legien Agreement}

The Stinnes-Legien Agreement provides a second example of pacification. A group of industrialists and union leaders signed this agreement on November 15, 1918. It included major concessions to labor, including the eight-hour workday, recognition of labor unions, a right to establish works councils, and the adoption of sectoral collective bargaining. In turn, the union leaders promised to cooperate with employers in organizing demobilization and a peaceful transition to a postwar order. ${ }^{49}$ The agreement effectively created the "German model" of industrial relations, which today is often seen as providing competitive advantages. The agreement, however, was not the result of far-sighted industrialists trying to establish institutions beneficial to labor productivity; it was, rather, an attempt to ward off a social revolution.

Following Germany's defeat in the First World War, a series of events had taken place that led to the collapse of the empire and the proclamation of a socialist republic by the "workers' councils," a grassroots

\footnotetext{
${ }^{46}$ The radical wing within the party insisted that only a social revolution could lead to socialism. Cf. Lidtke 1966, 230-33.

${ }^{47}$ Hohorst, Kocka, and Ritter 1978, 173-75.

${ }^{48}$ Data from Ritter and Tenfelde 1975, 120.

${ }^{49}$ Reichert 1919, 21-22; Weber 1954, 117-18.
} 
movement inspired by the Russian Revolution one year earlier. ${ }^{50}$ The movement called for a republic governed by workers' councils following the Soviet model. The movement appeared to command considerable popular support in the immediate aftermath of the war, a period characterized by economic and political chaos. A particularly salient problem for social and political stability was the sudden return of a large number of soldiers from the front, men who were armed and without jobs and therefore potentially receptive to a revolutionary pitch. In this context, a group of industrialists took the initiative to forge an agreement with moderate union leaders with the goal of gaining the unions' cooperation in their effort to handle political instability. ${ }^{51}$

The agreement reflects a sudden change of course. Only a few months earlier, employers had adamantly rejected union calls for institutionalized cooperation. ${ }^{52}$ The adoption of works councils and arbitration boards illustrates this point: the War Auxiliary Services Law, adopted in 1916, established mandatory works councils and arbitration boards in firms that relied on compulsory labor. The adoption of these institutions was a government concession to ensure union acquiescence. Industrialists accepted this law as a temporary measure and hoped to be able to restore the prewar authoritarian approach to labor relations once the war was won. In March 1918 the employer federation VDA (Vereinigung deutscher Arbeitgeberverbände), for instance, declared:

The War Auxiliary Services Law is an emergency law, necessitated by the exigencies of war. Obviously, no reason exists for its continuation after a [victorious] peace agreement.... Indeed, also the institutions created by the law [that is, works councils and arbitration boards] should be abolished. ${ }^{53}$

In a similar way, Fritz Tänzler, the executive director of the VDA, argued in early 1918 that "the free development of wages ... [will be] stifled by the legislative regulation of wage bargaining. ... [L] egislative regulation ... will necessarily lead ... to compulsion. ${ }^{54} \mathrm{~A}$ few months later, the VDA endorsed the Stinnes-Legien Agreement, which made mandatory works councils and collective wage bargaining permanent.

The timing of the talks further illustrates the causal role of political instability. Two civil servants had initiated talks between union and industry leaders as early as May 1917, but these talks broke down in

${ }^{50}$ Carr 1979, 248-50; Michalka and Niedhart 1992, 21.

${ }^{51}$ Feldman 1970, 334.

${ }^{52}$ Cf. Kocka 1984, 69.

${ }^{53}$ VDA memorandum of March 1918, quoted in Leckebusch 1966, 68. Cf. also Braun 1927, 35-36; Raumer 1954, 426-28; Tänzler 1918, 2.

${ }^{54}$ Tänzler 1918, 1-2. 
October of that year because expectations of a victory induced industrialists to hope for a return to prewar authoritarianism. ${ }^{55}$ Negotiations resumed only in October 1918, when Germany's defeat, not expected one year earlier, was imminent. This time, industry did not have to be cajoled into negotiations but took the initiative. From then on, negotiations proceeded very quickly and, as mentioned earlier, the agreement was signed less than two months later.

Reports by Hans von Raumer ${ }^{56}$ and by Jakob Reichert, ${ }^{57}$ two leading industry representatives in the negotiations, reveal the internal deliberations of the industrialists involved. Reichert reports about a meeting of a group of iron and steel industrialists in Düsseldorf on October 9, 1918. According to his account, the participants agreed that:

What was important was: How can one rescue industry? How can ... the entrepreneurs be saved from socialization ... and the approaching revolution? ... Those assembled shared the view that the government ... would soon collapse. ... In any case, the iron industrialists could expect no help from a weak government. . . . Organized labor only seemed to have a commanding influence. From this the conclusion was drawn that, in the midst of great general uncertainty, the failing power of the state and the government, strong allies for industry could be found only among the workers, and that means the unions. ${ }^{58}$

In a similar way, Ewald Hilger, a Silesian coal mine director, confessed at a meeting of the executive committee of the German Association of Iron and Steel Industrialists on November 14, 1918:

I stand before you as a Saul become Paul. Unless we negotiate with the unions we can go no further. Yes, gentlemen, we should be happy that the unions are still prepared to negotiate as they have; for only by negotiation ... with the unions ..., can we avoid anarchy, bolshevism, Spartacist rule and chaos-call it what you will. ${ }^{59}$

In short, internal deliberations document that fears of a social revolution motivated the concessions.

Remarkably, a group of individual industrialists, not the employers' associations, engineered the agreement. The participating industrialists were mainly from manufacturing, but some also came from heavy

\footnotetext{
${ }^{55}$ Feldman 1970, 323-24; Leckebusch 1966, 71.

${ }^{56}$ Raumer was the executive director of the Association of the German Electric Engineering Industry and masterminded the agreement.

${ }^{57}$ Reichert was the executive director of the Association of German Iron and Steel Industrialists.

${ }^{58}$ Reichert 1919, 6, emphasis added. A part of the translation is from Feldman 1970, 327.

${ }^{59}$ Quoted in Maier 1975, 60.
} 
industry. ${ }^{60}$ These industrialists acted without an official mandate from the peak federations. ${ }^{61}$ The peak federations initially protested against the agreement ${ }^{62}$ but eventually decided to endorse it. ${ }^{63}$ Opposition to the agreement came from medium-size industries, clothing and textiles, and regional associations in Rhineland and Saxony. These groups thought that the comparatively quiet situation in their regions or sectors did not require such far-reaching concessions. ${ }^{64}$ In short, there was disagreement within industry, but the urgency of the situation allowed the protagonists to ignore the dissenters.

Once the revolutionary threat had waned, business support for laborfriendly policies waned as well. Employers withdrew some of the concessions made in the agreement, in particular the eight-hour workday ${ }^{65}$ The employer federations also campaigned against the Works Councils Law of 1920, despite having accepted compulsory works councils in the agreement. In 1919 the VDA's general assembly declared that "the introduction of works councils ... [would] mean such [a] deep intervention in the entrepreneur's right to self-determination ... that ... damage to the enterprises and the whole industry would be the consequence." ${ }^{6}$

Some industrialists urged their fellow industrialists to continue the strategy of pacification after the revolutionary moment had subsided, but their influence within the business community waned. In 1923 Carl Duisberg, director of the chemicals company IG Farben and future president of the Federation of German Industry (Reichsverband deutscher Industrie, RDI), wrote:

Many believe the situation created by the revolution is only temporary; things will slowly get back on the old rails again. One cannot warn too much of this view. In foreign policy, as well as in social policy, we have always reacted too late.... We always have to remain aware that bolshevist Russia stands in the east. There, only ... one goal exists, to establish the dictatorship of the proletariat all over Europe. ${ }^{67}$

${ }^{60}$ The participating industrialists included Carl Friedrich von Siemens (electrical engineering), Walter Rathenau (Allgemeine Elektrizitäts-Gesellschaft, AEG, electrical engineering), Felix Deutsch (AEG), Anton von Rieppel (Maschinenfabrik Augsburg-Nürnberg, MAN, machine building), Ernst von Borsig (Borsigwerke, machine building, president of VDA), Albert Vögler (Vereinigte Stahlwerke, heavy industry), and Hugo Stinnes (Hugo Stinnes GmbH, heavy industry). See Reichert 1919, 8.

${ }^{61}$ See Raumer 1954, 430.

${ }^{62}$ Feldman 1970.

${ }^{63}$ See Raumer 1954, 428; and Reichert 1919, 8-11.

${ }^{64}$ Feldman 1970, 339-40.

${ }^{65}$ Erdmann 1966, 136.

${ }^{66}$ Braun 1927, 46.

${ }^{67}$ Duisberg 1923, 68. 
The political stabilization during the following years led these voices to subside, however.

\section{EMPloyers' STRATEgy of CONTAINMENT}

Once revolutionary challenges had subsided, containment of social expenditures became employers' primary goal. The Social Democrats and the nonpartisan union federation (Deutscher Gewerkschaftsbund, DGB) officially abandoned their collectivization goals in their $1959 \mathrm{Bad}$ Godesberg and 1963 Düsseldorf platforms, respectively. For employers, pacification had thus lost its original purpose. ${ }^{68}$ At the same time, welfare state expansion confronted employers with a new challenge: rising labor costs. As early as 1924 , when the revolutionary moment had already subsided, the VDA urged a reduction in social expenditures in order to "increase production and productivity." ${ }^{69}$ Welfare state expansion returned to the political agenda during the period of the "economic miracle" in the 1950s. Economic growth and rising labor productivity during this period attenuated distributive conflicts and, after the cataclysms of the Weimar and Nazi periods, employers and unions both came to embrace social compromise. This does not mean, however, that a genuine convergence of policy preferences took place. As in the Weimar period, employers tried to limit the scope and generosity of expansionary reforms initiated by others.

\section{Containment I: Unemployment Insurance}

Germany adopted statutory unemployment insurance in 1927 based on a broad political consensus: all parliamentary parties voted in favor of the law, except for the Communists, the Nazis, and some deputies of the far-right German National People's Party. ${ }^{70}$ Unions and employers also participated in the policy-making process. By contrast, when the issue of unemployment insurance first arose in the 1890s, most political actors either opposed such a program or were internally divided. Support for statutory unemployment insurance at that time came mainly from within the Catholic Center Party (Zentrum) and the leftwing liberals. At that time, only unions and some municipalities provided benefits to the unemployed. The unions opposed a statutory insurance program because it would have crowded out their own programs,

\footnotetext{
${ }^{68}$ See Alber 1989, 62; Van Hook 2004, 125-26.

${ }^{69}$ Tänzler 1924, 2.

${ }^{70}$ Faust 1987, 276.
} 
depriving them of a tool of mobilization. The Social Democrats were split, but a majority supported the unions' position. ${ }^{71}$

Employers initially opposed any support for the unemployed, whether public or union sponsored. They feared that unemployment benefits would raise the reservation wage and thus erode work incentives. ${ }^{72}$ The employers' association of Nuremberg-Fuerth, for instance, argued in 1914 that unemployment insurance would "degrade the productivity of our people.... The necessity to look for work would more or less cease." ${ }^{73}$ The peak federation VDA presented unemployment insurance as a "premium on laziness." ${ }^{\text {4 }}$ The diligent workers would end up subsidizing the indolent. These views continued to exist after the First World War. Ewald Hilger, the mine director mentioned earlier, pointed out in 1919 that "[these] workers are not unemployed but unwilling to work. Above all else they want to avoid difficult labor because they now have much better unemployment insurance." 75 Similarly, the VDA's official periodical argued in 1920 that "[a] statutory insurance against unemployment would lead to carelessness among the lower classes, and even provide opportunities for idleness." ${ }^{76}$ In short, employers suspected unemployment insurance would lead to an erosion of labor productivity and work incentives.

Despite these objections, the VDA eventually decided to cooperate in the drafting of the government bill. This shift in position can be traced to changes in the political context: first, after the war, a majority of unions and the moderate wing within the Social Democrats came to back a public program, although some unions and the radical left continued to oppose statutory unemployment insurance. ${ }^{77}$ This shift was a response to the massive rise in unemployment after the war, which made the unions' Ghent schemes financially unsustainable. Second, the democratization of the political system provided the Social Democrats and the Center Party with a greater say in policy-making. Throughout the 1920-27 period of policy-making, Heinrich Brauns (Center), a supporter of unemployment insurance, was the minister of labor. ${ }^{78}$ Third, and most important, the 1914 adoption of a means-tested program to support the unemployed, called unemployment assistance,

\footnotetext{
${ }^{71}$ Führer 1990, 52-61.

72 See Reiswitz 1904, 54-55; vDA 1914, 18; Zahnbrecher 1914, 19.

${ }^{73}$ Zahnbrecher 1914, 34.

${ }^{74}$ VDA 1914, 18.

${ }^{75}$ Hilger on March 1, 1919, as translated in Maier 1975, 60.

${ }^{76}$ DAGZ 1920, 1.

${ }^{77}$ Führer 1990, 189-201; Lewek 1992, 9.

${ }^{78}$ See Führer 1990, 172-73.
} 
changed the policy status quo against which all actors had to evaluate the pros and cons of unemployment insurance. The government initially intended unemployment assistance as a temporary program for the period of the war, but the program was continued after the war as part of the efforts to quell the revolutionary challenge in 1918-19.79

For employers, these changes mattered in two ways. First, the emergence of a political majority in favor of unemployment insurance limited the policy options available. Second, unemployment assistance turned unemployment insurance into a lesser evil. Employers disliked unemployment assistance even more than unemployment insurance, because the former provided benefits irrespective of employment record. Employers understood that dismantling the assistance program without a substitution was not politically feasible; the program would have to be replaced with something else. In short, it made strategic sense for employers to drop their opposition to unemployment insurance and cooperate with the government bureaucracy in drafting the new program. They could thereby achieve two goals: first, the replacement of unemployment assistance with a less problematic program, and second, the shaping of relevant policy details of the new program.

Proceedings of internal meetings and conferences of the two peak federations document these strategic motives. The Federation of German Industry was the first business federation to officially consider a change in position. At an internal meeting held on December 16, 1920, the RDI's social policy committee discussed the issue. Sixteen members voted in favor of unemployment insurance, five voted against. The chair of the committee, the plant director Hubert Hoff, invoked two arguments in favor of unemployment insurance. First, there would be only two options available: unemployment insurance and unemployment assistance. The third option, dismantling unemployment assistance without a replacement, would not have "a reasonable chance of success." Second, unemployment insurance would be the lesser of the two evils, because "if the system of unemployment assistance is continued, the employer has no influence over the use of the funds." 0

The VDA appears to have been torn initially but eventually also came around to backing the reform. Like the RDI, the VDA was dominated by big industry. The change in position can be traced to a meeting of the VDA's social policy committee on January 27, 1925. Thus, at this meeting, after the federation had campaigned against unemployment

${ }^{79}$ Lewek 1992, 9, 404; Wermel and Urban 1949, 13-15.

${ }^{80}$ Decision of the RDI executive board reported in RDI 1921. Statements by Hoff reported in Führer 1990, 211. 
insurance for several years, the committee endorsed the adoption of unemployment insurance. ${ }^{81}$

By that time, all other major actors had already come to back unemployment insurance, and employers remained the last important actor holding out against it. ${ }^{82}$ The VDA's social policy committee concluded that a strategy of fundamental opposition had "no reasonable chance" of success. ${ }^{83}$ The committee decided that the VDA would participate in the drafting of the bill to ensure consideration of its concerns, while maintaining its opposition in public. ${ }^{84}$

The Association of German Chambers of Industry and Commerce (Deutscher Industrie- und Handelstag, DIHT), which represented smaller firms, declared in 1920 that it had "fundamental objections" to unemployment insurance but would nonetheless be ready to participate in the drafting of the law. ${ }^{85} \mathrm{~A}$ statement by Stefan Oppenheimer, executive director of the Association of the Berlin Metal Industry, made at a conference of policy experts on February 20, 1925, further illustrates employers' strategic motives:

The employers' side understands that, given the proposals put forward by all political parties, it would be completely useless to take the position that we do not want any unemployment insurance. Therefore, the position of the employers is to say merely: unemployment insurance has to remain within tolerable limits, and it is our duty to point out the dangers that it could pose to the economy. ${ }^{86}$

In short, minutes of internal meetings provide significant evidence for containment as the main motive.

At the same time, the historical record provides little indication that concerns about skill investments would have motivated employers' about-turn. On the contrary, employers' stances on job suitability criteria contradict this hypothesis. These criteria defined what type of jobs recipients could decline without losing their benefits. The third government draft of the unemployment insurance bill, presented in 1925 , included a provision that required labor-market agencies to take into account a recipient's vocational training and occupational history

${ }^{81}$ Führer 1990, 218

${ }^{82}$ Lewek 1992, 231.

${ }^{83}$ Meeting of the VDA social policy committee on January 27, 1925. See Führer 1990, 218.

${ }^{84}$ Führer 1990, 218.

${ }^{85}$ See Deutscher Industrie- und Handelstag 1920, 56.

${ }^{86}$ Statement made at a conference of the German Society for the Fight against Unemployment held on February 20, 1925, in Berlin. The minutes of the conference are published as Jastrow, Erdmann, and Spliedt, 1925, quote by Oppenheimer, at 113. 
when determining whether that person could reject an offer. ${ }^{87}$ Remarkably, the VDA opposed this provision as too costly. The federation insisted that "[c]oncerning job suitability, previous vocational training should not be taken into consideration." ${ }^{88}$ The DIHT also rejected restrictions on what qualifies as a "suitable job." ${ }^{99}$ In short, these positions contradict the motives expected by the business interests thesis. German employers showed no interest in protecting the skills investments of the unemployed.

Did this about-turn encompass all segments of business, or did the issue divide business along sectoral lines? The evidence suggests that sectoral conflicts were of secondary importance. First, the positions of business were articulated primarily by the national peak federations, rather than by sectoral associations. Second, there appear to be no substantial differences between the arguments advanced by the federations representing big industry (RDI, VDA) and by the one representing smaller firms (DIHT). There is evidence, however, that not all businessmen followed the federations' change of tack. Although the VDA recommended that deputies vote in favor of the bill, several deputies affiliated with business voted against it or abstained. Although these deputies came from various sectors and represented both small and large firms, they belonged predominantly to the right-wing German National People's Party, which opposed the bill..$^{90}$ Their voting behavior thus reflected their partisan affiliation rather than differences in sectoral interests.

Remarkably, the employers' federations' endorsement of unemployment insurance was also short-lived. With the onset of the Great Depression two years after passage of the law, the costs of the new program soared. Employers revoked the 1927 compromise and demanded a return to means testing in order to reduce expenditures. ${ }^{91}$

\section{Containment II: The Pension Reform of 1957}

Postwar efforts to expand benefit generosity in social programs provide another instance of containment. In 1957 Germany adopted a major reform of its pension system. Hitherto, pension benefits had not been indexed and were at a level of about one-third of the average wage. ${ }^{92}$

\footnotetext{
${ }^{87}$ Lewek 1992, 269.

${ }^{88}$ VDA 1926,36 , see also 36R.

${ }^{89}$ Deutscher Industrie- und Handelstag 1920, 56.

${ }^{90}$ The list of business deputies who voted against the bill is reported in Führer 1990, 220-21.

${ }^{91}$ Büren 1934, 211-12; Weisbrod 1978, 210.

${ }^{92}$ Schmidt 1998, 73.
} 
The reform, which was a landmark event in postwar social policy expansion, included a onetime increase of pensions by about 65 percent on average and an indexation of pensions to gross wages. ${ }^{93}$

Parliament passed the reform on January 22, 1957, with the votes of the governing Christian Democrats (CDU) and the opposition Social Democrats (SPD), while the CDU's coalition partner, the market-liberal Free Democrats (FDP) voted against it. ${ }^{4}$ The initiative for the reform came from the Federal chancellor, Konrad Adenauer, of the Christian Democratic Party (Christlich Demokratische Union, CDU), who promoted welfare expansion to improve his chances of reelection.

Employers opposed the reform, in particular, the wage indexation of pensions. While a plan by a Catholic entrepreneur, Wilfried Schreiber, provided the blueprint for the reform,${ }^{95}$ the Federation of German Employers' Associations (Bundesvereinigung deutscher Arbeitgeberverbände, $\mathrm{BDA}$ ) and the insurance sector opposed the plan, albeit for somewhat different reasons. The insurance sector opposed the reform because it feared that private pensions would be crowded out. ${ }^{96}$ The employers' federation feared an increase in labor costs.

Given the support of the two largest parties in parliament (SPD and $\mathrm{CDU}$ ), employers realized that fundamental opposition would be ineffectual. Adjusting to the political situation, the BDA decided to propose an alternative way of adjusting pension benefits. Rather than raising pensions automatically through an indexation formula, an expert committee would raise pensions from time to time depending on the trend in average living standards. ${ }^{97}$ In this way, the BDA thought, pension expenditures could be contained more effectively. In 1956 BDA president Hans C. Paulssen and BDA executive director Gerhard Erdmann met several times with Chancellor Adenauer to discuss the issue, but Adenauer apparently ignored their concerns. ${ }^{98}$

The insurance sector presented its own alternative. In May 1956 the Association of Private Life Insurers proposed a uniform flat-rate pension for everyone, which it hoped would allow greater scope for private pensions. ${ }^{99}$ However, like the $\mathrm{BDA}$, the insurance sector also failed to get its way. The Free Democrats were the only parliamentary faction that supported this proposal. ${ }^{100}$

\footnotetext{
${ }^{93}$ Hockerts 1980, 434.

${ }^{94}$ See Hockerts 1980, 434.

${ }^{95}$ Schreiber 1955.

${ }^{96}$ Hockerts 1980, 378.

${ }^{97}$ BDA 1956, 221-45.

${ }^{98}$ Hockerts 1980, 391-92; BDA 1957, 224.

${ }^{99}$ Bauer, Luzius, and Mehring 1956.

${ }^{100}$ Hockerts 1980, 387-88.
} 
In sum, the role of business in the pension reform of 1957 was characterized by the goal of containing benefit generosity. The employers' federation and the insurance sector had different motives for wanting to keep benefits low, but their preferences converged on the goal of limiting benefit generosity. In the absence of government plans to raise pensions considerably, neither of the two organizations would likely have taken any initiative on this issue, as in this case pensions would have remained low.

\section{Containment III: The Introduction of Long-Term Care INSURANCE IN 1994}

The adoption of statutory long-term care insurance in 1994 provides a third example of containment. This program was the last of the major statutory social insurance programs to be adopted. The program funds long-term nursing care for the elderly and, like the other insurance programs, relies on pay-as-you-go financing. The Christian Democratic minister of labor, Norbert Blüm, a representative of the party's labor wing, initiated and promoted its adoption. The issue divided the Christian Democrats: the party's labor wing and the churches favored statutory long-term care insurance, as did the Social Democrats and the labor unions. The CDU business wing opposed it. In the end, electoral considerations prompted the government to go ahead with the reform in June 1993. ${ }^{101}$

The business federations, fearing a rise in labor costs, lobbied vehemently against the adoption of the program. Relatively late in the reform process, realizing that they were unable to prevent its adoption, the four peak federations of business ${ }^{102}$ presented an alternative proposal. This proposal consisted of an obligation for all citizens above the age of twenty-five to take out private, prefunded long-term care insurance, in addition to the temporary use of public funds to support those too old to accumulate savings and subsidizing premiums for persons on low incomes. ${ }^{103}$ Despite employers' opposition and attempts to reach a compromise, the government went ahead with the reform. In retrospect, then-BDA president Klaus Murmann called the adoption of long-term care insurance "the greatest fiasco during my term of office." ${ }^{104}$

\footnotetext{
${ }^{101}$ Ritter 2007, 265.

${ }^{102}$ These federations are the Confederation of German Employer Associations (BDA), the Federation of German Industry (BDI), the German Diet of Industry and Commerce (DIHT), and the Confederation of Skilled Crafts (ZDH).

${ }^{103}$ See BDA 1991; Der Arbeitgeber 1992, 310; Murmann 1997, 165-66; and Süddeutsche Zeitung, September 15, 1993, 30.

${ }^{104}$ Murmann 1997, 165.
} 


\section{Shadow Cases: The United States and Sweden}

This section provides a brief discussion of the role of business in the development of the welfare states in Sweden and the United States. There may be reasons for the German case to have a bias against the business interests thesis. For example, political challenges may have played a greater role in shaping business positions in Germany than in other countries. This section therefore investigates the applicability to other cases of the argument developed in this article. The section focuses on Sweden and the United States, because proponents of the business interests thesis often focus on these two countries.

\section{SwEDEN}

Sweden is pivotal to the debate because of the generosity of its welfare state. Has this generosity been aided by Swedish business being more supportive of social policy than business in other countries? ${ }^{105}$ Much of the literature on Sweden highlights two types of class alliances as the driving forces behind the expansion of the welfare state: an alliance between the labor movement and agrarian interests, responsible for the adoption of universal programs in the first half of the twentieth century; and an alliance between blue-collar and white-collar employees, responsible for the adoption of earnings-related programs in the postwar period. ${ }^{106}$ Business interests do not play a major role in these cross-class alliance accounts. However, Peter Swenson has suggested that the generosity of the Swedish welfare state is in part the result of the absence of business opposition to policies that were opposed by business elsewhere. ${ }^{107}$ Walter Korpi has challenged Swenson's account and argued that changes in the balance of power resulted in employers adjusting their political stances. ${ }^{108}$

Indeed, an analysis of political context suggests that the absence of fundamental business opposition to social reforms in Sweden was part of a strategy of containment, rather than of promotion of welfare expansion. The adoption of a supplementary pension program (Allmänna Tillägspensionen, ATP) in 1959 provides an illustrative example of how business tried to limit the scope of reforms by offering conditional support. ${ }^{109}$ The reform plans resulted in a heated political debate and

\footnotetext{
${ }^{105}$ As argued by Peter Swenson. See Swenson 1991, 513-14; and Swenson 2002, 10.

106 Baldwin 1990, chap. 1; Esping-Andersen 1985; Manow 2009, 114.

${ }^{107}$ Swenson 1991, 514; Swenson 2002, 12.

${ }^{108}$ Korpi 2006, 186-93.

${ }^{109}$ This and the following paragraph draw on Molin 1965; Olsson 1990; and Stephens 1979.
} 
a popular referendum. The blue-collar union federation (Landsorganisationen i Sverige, LO) was the main protagonist of the reform. The employers' federation SAF (Svenska Arbetsgivareföreningen) was the main opponent, and the white-collar union federation (Tjänstemanens Centralorgansiationen, TCO) was divided. Political parties initially remained passive, but eventually the Conservatives as well as the Liberals supported the employers' line, while the Social Democrats joined the LO line. The Agrarian Party opted for raising the basic pension and against an earnings-related pillar. ${ }^{110}$

For the LO, the main goal was to equalize the pension benefits of blue-collar and white-collar employees. At that time, many white-collar employees already enjoyed earnings-related occupational pensions, while most blue-collar workers did not. The opponents' main objection concerned the setup of public funds to accumulate reserves for future pension payments ("AP funds"). ${ }^{111}$ They suspected that these funds would become a tool for greater government control over investments. In 1954, in order to prevent the reform, the SAF proposed a voluntary occupational pension plan, negotiated between the social partners, financed entirely by contributions from employers, and run by firms. ${ }^{112}$ However, the LO rejected this proposal. ${ }^{113}$ In 1959 a consultative referendum took place, during which the SAF supported a similar line. In short, the SAF's decision to back a collectively agreed-upon occupational pension plan appears to reflect a strategy of containment, rather than a deliberate plan to promote labor productivity. In the absence of the ATP proposal, employers would probably not have taken any initiative on occupational pensions.

\section{The United States}

The passage of the Social Security Act (SSA) in the US in 1935 is another prominent case in the debate about business and the welfare state. The main components of the SSA were the adoption of statutory programs for unemployment insurance and old-age pensions. The role of business interests in the formulation and adoption of this legislation is disputed: while some argue that the adoption of the SSA was the product of business demands, ${ }^{114}$ others maintain that the reform became

${ }^{110}$ The depiction of actors' positions draws on Olsson 1990, 218-20.

${ }^{111}$ Pontusson 1992, 79-80. As Pontusson shows, these fears turned out to be unfounded.

${ }_{112}$ Molin 1965, 132-33, 192.

${ }_{113}$ Olsson 1990, 219.

${ }^{114}$ Domhoff 1996; Gordon 1991; Gordon 1994; Jenkins and Brents 1991; Jenkins and Brents 1989; Quadagno 1984; Swenson 2002. 
possible only because of a political weakening of business following the Great Depression of 1929. ${ }^{115}$

To a large extent, business involvement in the policy-making process aimed at limiting the scope of the planned programs, as shown below. Whereas before the Great Depression, business universally opposed public social policy, as studies emphasizing the positive impact of business on the New Deal reforms acknowledge, ${ }^{116}$ a small group of executives from big industry eventually decided to accept government reform plans and to cooperate in their formulation. At the same time, a large segment of employers remained opposed to the reform, ${ }^{117}$ and the National Association of Manufacturers (NAM) attacked the Social Security bill in congressional hearings. ${ }^{118}$

The drafting of the bill that led to the SSA took place in the Committee on Economic Security (CES), set up for this purpose by President Roosevelt on June 29, $1934 .{ }^{119}$ Many of the executives and businessaffiliated policy experts who participated in the formulation of the bill represented firms that maintained occupational welfare plans. Before the Great Depression, these firms generally opposed public programs. During the Great Depression, many occupational plans turned out to be actuarially unsound, and some executives came to see a public pension program as a way to shift the cost burden to the state, allowing them to cut back on their own plans without labor protests. ${ }^{120}$

For the majority of firms, which did not have occupational pension plans, however, limiting the scope of the reforms was the main concern. The Great Depression, and the sense of political crisis it had induced, put the issue of welfare state reform on the political agenda. At the same time, Roosevelt's determination and the overwhelming Democratic majority in Congress made the passage of some form of welfare legislation appear inevitable to business. ${ }^{121}$

Internal memos of business interest groups document that strategies of containment motivated their involvement. One of the business interest groups involved in the work of the CES and its advisory council was Industrial Relations Counselors, Inc. (IRC), a consulting firm linked to Rockefeller interests. Some studies that stress the positive

\footnotetext{
115 Amenta and Parikh 1991; Hacker and Pierson 2002; Skocpol and Amenta 1985.

${ }_{116}$ Domhoff and Webber 2011, 150; Gordon 1991, 184.

${ }_{117}$ Amenta and Parikh 1991, 126-28.

${ }^{118}$ Witte 1963, 88-90.

${ }^{119}$ For the analysis of the CES, I draw in particular on a report written by the committee's executive director, Edwin E. Witte; Witte 1963.

${ }^{120}$ Gordon 1991, 184-86.

${ }^{121}$ Hacker and Pierson 2002, 295-98.
} 
impact of business interests on the New Deal reforms focus on this group and argue that it was a vehicle for communicating the preferences of progressive employers to government officials. ${ }^{122}$ In a Memorandum to Clients issued in 1934, the IRC argued that "it is patent that the Administration is determined to develop a program of social welfare to be presented at the next session in Congress, and that broad departures in the field of industrial relations may be anticipated." ${ }^{123}$ Henry Harriman, president of the US Chamber of Commerce, took a similar view. According to a report by Edwin E. Witte, the executive director of the CES, "[his] general attitude was that some legislation on social security was inevitable and that business should not put itself in the position of attempting to block this legislation, but should concentrate its efforts upon getting it into an acceptable form." ${ }^{24}$ Similarly, Marion Folsom of Eastman Kodak, one of the leading supporters of the New Deal reforms, argued that "employers must realize that the country is facing an old-age and an unemployment problem ... and that legislation to meet these problems is inevitable." 125 In short, strategic adjustment to a changed political context appears to have played a major role in shaping the positions of those business groups that cooperated in the drafting of the SSA. ${ }^{126}$

If we look at the proposals made by the business representatives involved in the drafting of the SSA, we can see that they often aimed at limiting the scope and generosity of the planned programs. Southern employers wanted to protect their low-wage labor market and succeeded in excluding agricultural and domestic workers from unemployment insurance. ${ }^{127}$ Some firms lobbied for employers with occupational pension plans to be allowed to opt out of public pensions, ${ }^{128}$ but Congress eventually turned down this proposal to avoid adverse selection problems. ${ }^{129}$ Business representatives in the CES's advisory council lobbied for employee contributions to unemployment insurance, but the CES decided in favor of contributions from employers only. ${ }^{130}$ In short, the changes that these business representatives pushed for aimed at limiting the negative effects of the planned programs on firms, rather than

${ }^{122}$ Domhoff and Webber 2011, 148-51; Swenson 2002, 205-8.

${ }^{123}$ IRS Memorandum to Clients, no. 1, 1934, 2. Quoted in Domhoff and Webber 2011, 167.

${ }^{124}$ Witte 1963, 89n52.

${ }^{125}$ Quoted in Hacker and Pierson 2002, 300.

${ }^{126}$ Some scholars who emphasize the impact of business on the New Deal reforms acknowledge the role of strategic accommodation. See Jenkins and Brents 1991, 130.

${ }^{127}$ Domhoff and Webber 2011, 186; Hacker and Pierson 2002, 304.

${ }^{128}$ Witte $1963,157-59$.

${ }_{129}$ Orloff 1993, 293; Witte 1963, 160-61.

${ }^{130}$ Domhoff and Webber 2011, 176; Hacker 2002, 302; Witte 1963, viii. 
promoting the passage of these programs as such. At the same time, existing studies provide little evidence of business groups pushing for more generous provisions than what was demanded by others. In short, the main goal of most business groups, except the small group of welfare capitalists, appears to have been containment.

\section{Implications of the Shadow Case Studies}

The shadow cases provide evidence for containment, but not for pacification. The absence of a credible revolutionary challenge in Sweden and the US seems to be the main explanation for the lack of pacification in these two cases. For the US, James Weinstein found that fears of working-class revolutionary movements motivated industrial leaders to back the social reforms of the Progressive Era (ca. 1900-1918). ${ }^{131}$ With regard to the SSA, however, business support was motivated by disadvantageous policy alternatives rather than by fears of socialism. In short, the shadow cases suggest that containment is likely to be a more frequent business strategy in welfare state politics than pacification, due to the greater prevalence of reformist challenges.

\section{CONCLusions}

This article has shown how political challenges have shaped employers' attitudes toward the adoption and expansion of welfare state programs. Existing employer-centered studies have focused mainly on sectoral variation, rather than on cross-temporal variation. The article has shown how the cross-temporal analysis of employers' social policy positions allows us to capture the impact of changes in political challenges on these positions.

The article has relied on three types of empirical implications to test the impact of political challenges to employers' attitudes toward welfare expansion. First, it used statements by employers' associations and internal reports to identify the motives behind specific policy positions. Second, it analyzed the stages of policy-making at which employers decided to intervene. I have shown that in potentially revolutionary situations, employers actively promoted social policies and labor participation rights in order to secure political stability. The main exemplars of this strategy are the proposals for social insurance by the CDI and the Baare group in the 1880s and the Stinnes-Legien Agreement in November 1918. By contrast, employers took a defensive stance

${ }^{131}$ Weinstein 1968 , ix-xi. 
when confronted with expansionary reform proposals in the absence of a revolutionary challenge. They typically became active only at an advanced stage of policy-making and promoted policy options that were less generous or less costly. The shadow cases show that containment was also a frequent goal of employers in Sweden and in the US, whereas pacification did not play a major role in these countries due to the absence of credible revolutionary challenges.

Third, the article investigated the relative importance of sectoral disagreements in the reform episodes by identifying the role of sectoral and peak-level organizations, respectively, in articulating business interests in the policy-making process. It found that in most reform episodes in Germany, the national peak federations were the dominant representatives of the social policy interests of business, while sectoral groups tended to take a back seat in social policy-making. An exception to this finding is the Stinnes-Legien Agreement, which was initiated by a group of individual industrialists, although the peak federations approved the agreement in retrospect. The rapid course of events during the revolutionary situation of November 1918 is likely to explain this deviation: their slow and bureaucratic processes of decision making did not allow the peak federations to respond in a timely way. In the Swedish ATP reform, the peak federation was the dominant actor as well. By contrast, sectoral conflicts played a greater role in the US New Deal reforms. However, even in the US case, political constraints were a much more important motive for business cooperation in the drafting of the SSA than the market-regulating interests of the small group of welfare capitalists.

The dominance of the peak federations does not mean that business is a monolithic bloc. However, internal disagreements often had diverse sources and were typically not strong enough to prevent employers from closing ranks when confronted with a political challenge. Disagreements often concerned details of policy design, rather than the ultimate goal employers wanted to achieve. For instance, in November 1918 employers disagreed about which concessions were necessary to pacify the population, but not on the need for pacification. ${ }^{132}$ In 1957 business groups disagreed on the policy alternatives best suited to contain the scope of the pension reform, but not on the need to scale back the government's plans.

The findings of the article have implications for the future sustainability of welfare state institutions. Some have argued that successful

${ }^{132}$ Feldman 1970, 339. 
adaptation to existing policies over time led employers to abandon their erstwhile opposition to labor-friendly institutions, thus causing a convergence of the policy preferences of capital and labor. ${ }^{133}$ By contrast, the model presented in this article suggests that with reformist challenges receding in recent decades, business support for social policy is likely to wane. While business will always try to adapt to the institutional environment, adaptation is likely to succeed only in part, leaving enough incentives for counterattacks when reformist forces recede. Several studies on Germany confirm this view. Studies by Daniel Kinderman and by Georg Menz document that in recent decades employers there have become more outspoken proponents of labor-market deregulation and welfare cutbacks than they were during the reformist postwar period. ${ }^{134}$ Studies of the development of German employers' attitudes toward unemployment insurance ${ }^{135}$ and employment protection, ${ }^{136}$ respectively, agree that employers' opposition to these policies hardly eroded over time and possibly increased during the last two decades.

Thus, if we look at employers' attitudes over the long term, we see a secular shift against social policy, from pacification, via containment of welfare expansion, to calls for welfare retrenchment. Looking ahead, a recurrence of the kind of political challenges that motivated business to back some forms of welfare state expansion appears unlikely. Today, in the context of fiscal austerity, strategic accommodation is more likely to explain the politics of labor, rather than that of business.

\section{REFERENCES}

Alber, Jens. 1989. Der Sozialstaat in der Bundesrepublik 1950-1983 [The Welfare State in the Federal Republic, 1950-1983]. Frankfurt am Main, Germany, and New York, N.Y.: Campus.

Amenta, Edwin, and Sunita Parikh. 1991. "Capitalists Did Not Want the Social Security Act: A Critique of the 'Capitalist Dominance' Thesis." American Sociological Review 56, no. 1 (February): 124-29.

Ayass, Wolfgang, Florian Tennstedt, and Heidi Winter, eds. 2003. Quellensammlung zur Geschichte der deutschen Sozialpolitik 1867 bis 1914: Von der Kaiserlichen Sozialbotschaft bis zu den Februarerlässen Wilhelm II. (1881-1890), vol. 1, Grundfragen der Sozialpolitik: Die Diskussion der Arbeiterfrage auf Regierungsseite und in der Öffentlichkeit [Sourcebook on the History of Social Policy in

${ }^{133}$ Hall 2007, 63; Hassel 2007, 254-55.

${ }^{134}$ Kinderman 2005, 433-35; Menz 2005, 198-200. Blyth notes a similar withdrawal of business support for labor-friendly institutions in Sweden. Blyth 2001, 1-2.

${ }^{135}$ Emmenegger and Marx 2011, 748.

${ }^{136}$ Brosig 2011, 325-30. 
Germany from 1867 to 1914: From the Imperial Message to the February Decrees of Wilhelm II (1881-1890), vol. 1, Basic Questions of Social Policy: The Discussion of the Workers' Question within Government and in Public]. Darmstadt, Germany: Wissenschaftiche Buchgesellschaft.

Baare, Louis. 1880. "Protokoll der Konferenz in Bochum am 2. und 3. November 1880." Potsdam, Germany: Bundesarchiv Potsdam.

Baldwin, Peter. 1990. The Politics of Social Solidarity: Class Bases of the European Welfare State, 1875-1975. Cambridge, UK: Cambridge University Press.

Bauer, W. , H. P. Luzius, and J. Mehring. 1956. Die elastische Staatsbürgergrundrente als Grundlage einer echten sozialen Reform: Verfasst auf Anregung eines Kreises von Versicherungsfachleuten [The Elastic Citizen's Basic Pension as a Foundation of True Social Reform: Written at the Suggestion of a Group of Insurance Experts]. Karlsruhe, Germany: Verlag der Versicherungswirtschaft.

BDA. 1956. Jahresbericht der Bundesvereinigung der Deutschen Arbeitgeberverbände, 1. Dez. 1955-30. Nov. 1956 [Annual Report of the Confederation of German Employers' Associations, December 1, 1955-November 30, 1956]. Cologne, Germany: Bundesvereinigung der Deutschen Arbeitgeberverbände.

- 1957. Jabresbericht der Bundesvereinigung der Deutschen Arbeitgeberverbände, 1. Dez. 1956-30. Nov. 1957 [Annual Report of the Confederation of German Employers' Associations, December 1, 1956-November 30, 1957]. Cologne, Germany: Bundesvereinigung der Deutschen Arbeitgeberverbände.

- 1991. Zur Neuordnung der Pflegeversicherung: Das Zwei-KomponentenModell der Arbeitgeber [On the Reorganization of Long-Term Care Insurance: The Employers'Two-Component Model]. Cologne, Germany: Bundesvereinigung der deutschen Arbeitgeberverbände.

Berlepsch, Hans-Jörg von. 1994. "Konsensfähige Alternativen zu Bismarcks Modell Sozialpolitischer Gestaltung." In Lothar Machtan, ed., Bismarcks Sozialstaat: Beiträge zur Geschichte der Sozialpolitik und zur Sozialpolitischen Geschichtsschreibung [Bismarck's Welfare State: Contributions to the History of Social Policy]. Frankfurt am Main, Germany: Campus.

Blyth, Mark. 2001. "The Transformation of the Swedish Model: Economic Ideas, Distributional Conflict, and Institutional Change." World Politics 54, no. 1 (October): 1-26.

Böhme, Helmut. 1966. Deutschlands Weg zur Grossmacht: Studien zum Verbältnis von Wirtschaft und Staat während der Reichsgründungszeit 1848-1881 [Germany's Path to Becoming a Superpower: Studies about the Relationship of Economy and State during the Founding Period of the Empire, 1848-1881]. Cologne and Berlin, Germany: Kiepenheuer und Witsch.

-1978. An Introduction to the Social and Economic History of Germany: Politics and Economic Change in the Nineteenth and Twentieth Centuries. New York, N.Y.: St. Martin's Press.

Braun, Egon. 1927. "Wandlungen des Arbeitgeberstandpunktes in der deutschen Industrie seit Beginn des 20. Jahrhunderts.” Ph.D. diss., University of Tübingen.

Breger, Monika. 1982. Die Haltung der industriellen Unternehmer zur staatlichen Sozialpolitik in den Jahren 1878-1891 [The Positions of Industrial Entrepreneurs toward Public Social Policy in the Years 1878-1891]. Frankfurt am Main, Germany: Haag + Herchen. 
. 1994. "Der Anteil der deutschen Großindustriellen an der Konzeptualisierung der Bismarckschen Sozialgesetzgebung." In Lothar Machtan, ed., Bismarcks Sozialstaat: Beiträge zur Geschichte der Sozialpolitik und zur sozialpolitischen Geschichtsschreibung [Bismarck's Welfare State: Contributions to the History of Social Policy]. Frankfurt am Main, Germany, and New York, N.Y.: Campus.

Brosig, Magnus. 2011. "Sozialpolitik als Hilfe für die Wirtschaft? Deutsche Arbeitgeber und die Systeme der Arbeitslosenversicherung." Zeitschrift für Sozialreform 57, no. 3: 313-37.

Bueck, Henry Axel. 1905. Der Centralverband Deutscher Industrieller, 1876-1901 [The Central Association of German Industrialists, 1876-1901]. Berlin, Germany: J. Guttentag.

Büren, Herbert. 1934. "Arbeitgeber und Sozialpolitik: Untersuchung über die grundsätzliche Haltung des deutschen Unternehmertums gegenüber der Sozialpolitik in der Vorkriegs-, Kriegs- Und Nachkriegszeit. I. Band.” Ph.D. diss., University of Cologne.

Carr, William. 1979. A History of Germany, 1815-1945. London, UK: Edward Arnold.

DAGZ. 1920. "Die moralischen Gefahren der reichsgesetzlichen Regelung der Arbeitslosen-Versicherung." Die Deutsche Arbeitgeber-Zeitung: Zentralblatt deutscher Arbeitgeberverbände. October 31, no. 44: 1-2.

Der Arbeitgeber. 1992. "Gemeinsame Erklärung zur Neuordnung der Pflegeabsicherung.” Der Arbeitgeber. May 15: 310.

Deutscher Industrie- und Handelstag. 1920. "Arbeitslosenversicherung." Handel und Gewerbe: Zeitschrift für die zur Vertretung von Handel und Gewerbe gesetzlich berufenen Körperschaften: Im Auftrag des Deutschen Industrie- und Handelstags. November 6: 56-57.

Domhoff, G. William. 1996. State Autonomy or Class Dominance? Case Studies on Policy Making in America. New York, N.Y.: De Gruyter.

Domhoff, G. William, and Michael J. Webber. 2011. Class and Power in the New Deal: Corporate Moderates, Southern Democrats, and the Liberal-Labor Coalition. Stanford, Calif:: Stanford University Press.

Duisberg, Carl. 1923. "Soziale Gegensätze und ihre Überwindung.” Der Arbeitgeber 13, no. 5 (February 15): 67-69.

Emmenegger, Patrick, and Paul Marx. 2011. "Business and the Development of Job Security Regulations: The Case of Germany." Socio-Economic Review 9, no. 4: 729-56.

Erdmann, Gerhard. 1966. Die deutschen Arbeitgeberverbände im sozialgeschichtlichen Wandel der Zeit [The German Employers' Associations through the Changing Periods of Social History]. Neuwied, Germany: Luchterhand.

Esping-Andersen, Gøsta. 1985. Politics against Markets: The Social Democratic Road to Power. Princeton, N.J.: Princeton University Press.

- 1990. The Three Worlds of Welfare Capitalism. Princeton, N.J.: Princeton University Press.

Faust, Anselm. 1987. "Von der Fürsorge zur Arbeitsmarktpolitik: Die Errichtung der Arbeitslosenversicherung." In Werner Abelshauser, ed., Die Weimarer Republik als Woblfabrtsstaat [The Weimar Republic as a Welfare State]. Stuttgart, Germany: Steiner. 
Feldman, Gerald D. 1970. "German Business between War and Revolution: The Origins of the Stinnes-Legien Agreement." In Gerhard A. Ritter, ed., Entstebung und Wandel der modernen Gesellschaft: Festschrift für Hans Rosenberg zum 65. Geburtstag [Origins and Change of Modern Society: A Festschrift for Hans Rosenberg's 65th Birthday]. Berlin, Germany: Walter de Gruyter Co.

Francke, L. 1881. "Die Stimmen der deutschen Handels- und Gewerbekammern über das Haftpflicht-Gesetz vom 7. Juni 1871 und dem Reichs-Unfallversicherungs-Gesetzentwurf vom 8. März 1881." Zeitschrift des Königlich-Preussischen Statistischen Bureaus 21: 397-416.

Führer, Karl Christian. 1990. Arbeitslosigkeit und die Entstehung der Arbeitslosenversicherung in Deutschland 1902-1927 [Unemployment and the Origins of Unemployment Insurance in Germany, 1902-1927]. Berlin, Germany: Colloquium.

Gordon, Colin. 1991. "New Deal, Old Deck: Business and the Origins of Social Security, 1920-1935." Politics and Society 19, no. 2 (June): 165-207.

- 1994. New Deals: Business, Labor, and Politics in America, 1920-1935. New York, N.Y.: Cambridge University Press.

Grote, Jürgen R., Achim Lang, and Franz Traxler. 2007. "Germany." In Franz Traxler and Gerhard Huemer, eds., Handbook of Business Interest Associations, Firm Size and Governance: A Comparative Analytical Approach. London, UK, and New York, N.Y.: Routledge.

Hacker, Jacob. 2002. The Divided Welfare State: The Battle over Public and Private Social Benefits in the United States. Cambridge, UK: Cambridge University Press.

Hacker, Jacob S., and Paul Pierson. 2002. "Business Power and Social Policy: Employers and the Formation of the American Welfare State." Politics and Society 30, no. 2 (June): 277-325.

Hall, Peter A. 2007. “The Evolution of Varieties of Capitalism in Europe.” In Bob Hancké, Martin Rhodes, and Mark Thatcher, eds., Beyond Varieties of Capitalism: Conflict, Contradiction, and Complementarities in the European Economy. Oxford, UK: Oxford University Press.

Hall, Peter A., and David Soskice. 2001. "An Introduction to Varieties of Capitalism." In Peter A. Hall and David Soskice, eds., Varieties of Capitalism: The Institutional Foundations of Comparative Advantage. New York, N.Y.: Oxford University Press.

Hassel, Anke. 2007. "What Does Business Want? Labour Market Reforms in CMEs and Its Problems." In Bob Hancké, Martin Rhodes, and Mark Thatcher, eds., Beyond Varieties of Capitalism: Conflict, Contradiction, and Complementarities in the European Economy. Oxford, UK: Oxford University Press.

Hellwig, Timothy T. 2005. "The Origins of Unemployment Insurance in Britain." Social Science History 29, no. 1 (Spring): 107-36.

Hennock, E. Peter. 2007. The Origin of the Welfare State in England and Germany, 1850-1914: Social Policies Compared. New York, N.Y.: Cambridge University Press.

Hockerts, Hans Günter. 1980. Sozialpolitische Entscheidungen im Nachkriegsdeutschland: Allierte und deutsche Sozialversicherungspolitik 1945-1957 [Social Policy Decisions in Postwar Germany: Allied and German Social Insurance Policies]. Stuttgart, Germany: Klett-Cotta. 
Hohorst, Gerd, Jürgen Kocka, and Gerhard Albrecht Ritter. 1978. Sozialgeschichtliches Arbeitsbuch: Materialien zur Statistik des Kaiserreichs 1870-1914 [Social Historical Handbook: Statistical Material about the Empire, 1870-1914]. Munich, Germany: Beck.

Huber, Evelyne, and John D. Stephens. 2001. Development and Crisis of the Welfare State: Parties and Policies in Global Markets. Chicago, Ill., and London, UK: University of Chicago Press.

Iversen, Torben, and David Soskice. 2009. "Distribution and Redistribution: The Shadow of the Nineteenth Century." World Politics 61, no. 3 (July): 438-86.

Jastrow, Ignaz, Gerhard Erdmann, and Franz Spliedt. 1925. Das Problem der Arbeitslosenversicherung in Deutschland: Verhandlungen der Deutschen Gesellschaft zur Bekämpfung der Arbeitslosigkeit am 20. Februar 1925 zu Berlin mit Berichten [The Problem of Unemployment Insurance in Germany: Proceedings of a Conference by the German Society for the Fight against Unemployment on February 20, 1925, in Berlin, with Reports]. Berlin, Germany: Reimar Hobbing.

Jenkins, J. Craig, and Barbara G. Brents. 1989. "Social Protest, Hegemonic Competition, and Social Reform: A Political Struggle Interpretation of the Origins of the American Welfare State." American Sociological Review 54, no. 6 (December): 891-909.

- 1991. "Capitalists and Social Security: What Did They Really Want?" American Sociological Review 56, no. 1 (February): 129-32.

Kaelble, Hartmut. 1967. Industrielle Interessenpolitik in der Wilhelminischen Gesellschaft: Centralverband Deutscher Industrieller 1895-1914 [Industrial Interest Politics in Wilhelmine Society: The Central Association of German Industrialists, 1895-1914]. Berlin, Germany: de Gruyter.

Kinderman, Daniel. 2005. "Pressure from Without, Subversion from Within: The Two-Pronged German Employer Offensive." Comparative European Politics 3, no. 3 (December): 432-63.

Kocka, Jürgen. 1984. Facing Total War: German Society, 1914-1918. Cambridge, Mass.: Berg.

Korpi, Walter. 1983. The Democratic Class Struggle. London, UK, and Boston, Mass.: Routledge and Kegan Paul.

- 2006. "Power Resources and Employer-Centered Approaches in Explanations of Welfare States and Varieties of Capitalism: Protagonists, Consenters, and Antagonists." World Politics 58, no. 2 (January): 167-206.

Leckebusch, Roswitha. 1966. Entstehung und Wandlung der Zielsetzungen, der Struktur und der Wirkungen von Arbeitgeberverbänden [Origins and Change in the Goals, Structure and Impact of Employers' Assocations]. Berlin, Germany: Duncker \& Humblot.

Levine, Rhonda F. 1988. Class Struggle and the New Deal: Industrial Labor, Industrial Capital, and the State. Lawrence, Kans.: University Press of Kansas.

Lewek, Peter. 1992. Arbeitslosigkeit und Arbeitslosenversicherung in der Weimarer Republik 1918-1927 [Unemployment and Unemployment Insurance in the Weimar Republic, 1918-1927]. Stuttgart, Germany: Franz Steiner.

Lidtke, Vernon L. 1966. The Outlawed Party: Social Democracy in Germany, 18781890. Princeton, N.J.: Princeton University Press.

Maier, Charles S. 1975. Recasting Bourgeois Europe: Stabilization in France, Germany, and Italy in the Decade after World War I. Princeton, N.J.: Princeton University Press. 
Manow, Philip. 2009. "Electoral Rules, Class Coalitions and Welfare State Regimes, or How to Explain Esping-Andersen with Stein Rokkan.” Socio-Economic Review 7, no. 1 (January): 101-21.

Mares, Isabela. 1997. "Is Unemployment Insurable? Employers and the Development of Unemployment Insurance." Journal of Public Policy 17, no. 3 (September-December): 299-327.

2003a. The Politics of Social Risk: Business and Welfare State Development. Cambridge, UK: Cambridge University Press.

- 2003b. "The Sources of Business Interest in Social Insurance: Sectoral versus National Differences.” World Politics 55, no. 2 (January): 229-58.

Martin, Cathie Jo. 2004. "Reinventing Welfare Regimes: Employers and the Implementation of Active Social Policy." World Politics 57, no. 1 (October): 39-69.

Martin, Cathie Jo, and Duane Swank. 2011. "Gonna Party Like It's 1899: Party Systems and the Origins of Varieties of Coordination." World Politics 63, no. 1 (January): 78-114.

Menz, Georg. 2005. "Old Bottles-New Wine: The New Dynamics of Industrial Relations." German Politics 14, no. 2 (June): 196-207.

Michalka, Wolfgang, and Gottfried Niedhart. 1992. Deutsche Geschichte, 19181933: Dokumente zur Innen- und Aussenpolitik [German History, 1918-1933: Documents about Domestic and Foreign Policy]. Frankfurt am Main, Germany: Fischer.

Molin, Björn. 1965. Tjänstepensionsfragen: En Studie i svensk Partipolitik [The Supplementary Pensions Question: A Study in Swedish Party Politics]. Göteborg, Sweden: Akademieförlaget.

Murmann, Klaus 1997. Kontrakt für die Zukunft: Was mich berwegt [Contract for the Future]. Berlin, Germany: Brandenburgisches Verlagshaus.

Nijhuis, Dennie Oude. 2009. "Revisiting the Role of Labor: Worker Solidarity, Employer Opposition, and the Development of Old-Age Pensions in the Netherlands and United Kingdom.” World Politics 61, no. 2 (April): 296-329.

Oechelhäuser, Wilhelm. 1889. Soziale Tagesfragen [Current Social Issues]. Berlin, Germany: J. Springer.

Olsson, Sven E. 1990. Social Policy and the Welfare State. Lund, Sweden: Arkiv.

Orloff, Ann Shola. 1993. The Politics of Pensions: A Comparative Analysis of Britain, Canada, and the United States, 1880-1940. Madison, Wis.: University of Wisconsin Press.

Paster, Thomas. 2009. "Choosing Lesser Evils: The Role of Business in the Development of the German Welfare State from the 1880s to the 1990s." Ph.D. diss., European University Institute.

- 2011. "German Employers and the Origins of Unemployment Insurance: Skills Interest or Strategic Accommodation?” MPIfG Discussion Paper 11/05. Cologne, Germany: Max Planck Institute for the Study of Societies.

- 2012. The Role of Business in the Development of the Welfare State and Labor Markets in Germany: Containing Social Reforms. London, UK: Routledge.

Pontusson, Jonas. 1992. The Limits of Social Democracy: Investment Politics in Sweden. Ithaca, N.Y.: Cornell University Press.

Quadagno, Jill S. 1984. "Welfare Capitalism and the Social Security Act of 1935." American Sociological Review 49, no. 5: 632-47.

Raumer, Hans von. 1954. "Unternehmer und Gewerkschaften in der Weimarer Zeit.” Deutsche Rundschau 80: 425-34. 
RDI. 1921. Geschäftliche Mitteilungen für die Mitglieder des RDI [Newsletter to the Members of the Federation of German Industry] 3, no. 1. Berlin, Germany: Reichsverband deutscher Industrie.

Reichert, Jakob Wilhelm. 1919. Entstehung, Bedeutung und Ziel der "Arbeitsgemeinschaft" [Origins, Importance and Goals of the "Working Group"]. Berlin, Germany: Selbstverlag der Arbeitgemeinschaft.

Reiswitz, Willy Freiherr von. 1904. "Protokoll der Arbeitsnachweiskonferenz zu Hamburg, den 22. August 1903.” Hamburg, Germany: Arbeitgeberverband Hamburg-Altona.

Ritter, Gerhard A., ed., 2007. Geschichte der Sozialpolitik in Deutschland seit 1945, vol. 11, Bundesrepublik Deutschland, 1989-1994: Sozialpolitik im Zeichen der Wiedervereinigung [History of Social Policy in Germany since 1945, vol. 11, The Federal Republic 1989-1994: Social Policy against the Background of Reunification]. Baden-Baden, Germany: Nomos-Verlag.

Ritter, Gerhard A., and Klaus Tenfelde. 1975. "Der Durchbruch der Freien Gewerkschaften Deutschlands zur Massenbewegung im letzten Viertel des 19. Jahrhunderts." In Heinz O. Vetter, ed., Vom Sozialistengesetz zur Mitbestimmung: Zum 100. Geburtstag von Hans Böckler [From the Anti-Socialist Laws to Codetermination: Honoring the 100th Birthday of Hans Böckler]. Cologne, Germany: Bund-Verlag.

Schmidt, Manfred G. 1998. Sozialpolitik in Deutschland: Historische Entwicklung und internationaler Vergleich [Social Policy in Germany: Historical Development and International Comparison]. Opladen, Germany: Leske+Budrich.

Schreiber, Wilfried. 1955. Existenzsicherheit in der industriellen Gesellschaft: Vorschläge des Bundes Katholischer Unternehmer zur Reform der Sozialversicherungen [Financial Security in an Industrial Society: Proposals for the Reform of Social Insurance by the Federation of Catholic Entrepreneurs]. Cologne, Germany: Bund Katholischer Unternehmer.

Seeber, Gustav, and Gerd Fesser. 1994. "Linksliberale und Sozialdemokratische Kritik an Bismarcks Sozialreform." In Lothar Machtan, ed., Bismarcks Sozialstaat: Beiträge zur Geschichte der Sozialpolitik und zur sozialpolitischen Geschichtsschreibung [Bismarck's Welfare State: Contributions to the History of Social Policy]. Frankfurt am Main, Germany, and New York, N.Y.: Campus.

Shalev, Michael. 1983. "The Social Democratic Model and Beyond: Two Generations of Comparative Research on the Welfare State." Comparative Social Research 6: 315-51.

Skocpol, Theda. 1992. Protecting Soldiers and Mothers: The Political Origins of Social Policy in the United States. Cambridge, Mass.: Belknap Press of Harvard University Press.

Skocpol, Theda, and Edwin Amenta. 1985. "Did Capitalists Shape Social Security?” American Sociological Review 50, no. 4: 572-75.

Stephens, John D. 1979. The Transition from Capitalism to Socialism. London, UK: MacMillan.

Swenson, Peter A. 1991. "Bringing Capital Back In, or Social Democracy Reconsidered: Employer Power, Cross-Class Alliances, and Centralization of Industrial Relations in Denmark and Sweden." World Politics 43, no. 4 (July): 513-44.

- 2002. Capitalists against Markets: The Making of Labor Markets and Welfare States in the United States and Sweden. New York, N.Y.: Oxford University Press. 
2004. "Varieties of Capitalist Interests: Power, Institutions, and the Regulatory Welfare State in the United States and Sweden." Studies in American Political Development 18, no. 1 (April): 1-29.

Tänzler, Fritz. 1918. "Auf falscher Bahn?” Der Arbeitgeber: Zeitschrift der Vereinigung der Deutschen Arbeitgeberverbände, no. 1: 1-2.

_. 1924. "Am Wendepunkt?" Der Arbeitgeber 2.

Thelen, Kathleen A. 2001. "Varieties of Labour Politics in the Developed Democracies." In Peter A. Hall and David Soskice, eds., Varieties of Capitalism: The Institutional Foundations of Comparative Advantage. New York, N.Y.: Oxford University Press.

Ullmann, Hans-Peter. 1979. "Industrielle Interessen und die Entstehung der deutschen Sozialversicherung 1880-1889.” Historische Zeitschrift 229: 574-610.

Ullmann, Peter. 1977. Tarifverträge und Tarifpolitik in Deutschland bis 1914: Entstehung und Entwicklung, interessenpolitische Bedingungen und Bedeutung des Tarifvertragswesens für die sozialistischen Gerverkschaften [Wage Agreements and Wage Policy in Germany up to 1914: Origins and Development, Interest Politics and the Importance of Wage Agreements for the Socialist Unions]. Frankfurt am Main, Germany: Peter Lang.

Van Hook, James C. 2004. Rebuilding Germany: The Creation of the Social Market Economy, 1945-1957. Cambridge, UK: Cambridge University Press.

vDA. 1914. "Umschau." Der Arbeitgeber: Organ der Vereinigung der Deutschen Arbeitgeberverbände. January 15: 18-19.

—. 1926. "Stellungnahme zu den Grundfragen der Arbeitslosenversicherung." Berlin, Germany: Vereinigung der Deutschen Arbeitgeberverbände.

Vogel, Walter. 1951. Bismarcks Arbeiterversicherung: Ibre Entstehung im Kräftespiel der Zeit [Bismarck's Worker Insurance: Its Origins in the Power Play of the Times]. Braunschweig, Germany: Georg Westermann Verlag.

Weber, Adolf. 1954 Der Kampf zwischen Kapital und Arbeit: Gerwerkschaften und Arbeitgeberverbände in Deutschland [The Struggle between Capital and Labor: Unions and Employers' Associations in Germany]. Tübingen, Germany: Mohr.

Wehler, Hans-Ulrich. 1997. The German Empire, 1871-1918. Oxford, UK: Berg.

Weinstein, James. 1968. The Corporate Ideal in the Liberal State, 1900-1918. Boston, Mass.: Beacon Press.

Weisbrod, Bernd. 1978. Schwerindustrie in der Weimarer Republik: Interessenpolitik zwischen Stabilisierung und Krise [Heavy Industry in the Weimar Republic: Interest Politics between Stabilization and Crisis]. Wuppertal, Germany: Peter Hammer Verlag.

Wermel, Michael, and Roswitha Urban. 1949. "Arbeitslosenfürsorge und Arbeitslosenversicherung in Deutschland." Neue Soziale Praxis 6, no. 2: 111.

Witte, Edwin E. 1963. The Development of the Social Security Act: A Memorandum on the History of the Committee on Economic Security and Drafting and Legislative History of the Social Security Act. Madison, Wis.: University of Wisconsin Press.

Wood, Stewart. 2001. "Business, Government, and Pattern of Labor Market Policy in Britain and the Federal Republic of Germany." In Peter A. Hall and David Soskice, eds., Varieties of Capitalism: The Institutional Foundations of Comparative Advantage. New York, N.Y.: Oxford University Press.

Zahnbrecher, Franz X. 1914. Arbeitslosenversicherung und Arbeitgeber [Unemployment Insurance and Employers]. Nuremberg, Germany: Hofbuchhandlung Schrag. 